\title{
THE RELATIONSHIPS BETWEEN PHYSICAL ACTIVITIES AND DYSMENORRHEA IN ADOLESCENT THE CITY OF BANDUNG
}

\author{
Kusila Devia Rahayu ${ }^{1}$, Ira Kartika ${ }^{2}$, Rina Dayanti ${ }^{3}$ \\ ${ }^{1}$ Professional Nursing Study Program, ${ }^{2}$ Midwifery Diploma Study Program, ${ }^{3}$ Bachelor of Nursing Study \\ Program,STIKes Dharma Husada, Bandung, \\ Correspondence: kusila.rahayu@gmail.com
}

\begin{abstract}
Dysmenorrhea is a problem that often occurs in adolescents during menstruation. This study aimed to determine the relationship between physical activity and dysmenorrhea in adolescents in the city of Bandung. The study was a descriptive correlation study, with a cross-sectional approach. Samples were selected by the total sampling method, 68 female adolescents involved in this study. Physical activity was measured using a standard instrument, namely Baecke Physical Activity Scale and measurement of dysmenorrhea was measured using the Numeric Rating Scale pain scale. Data processing techniques used the Spearman Rank coefficient correlation. The results of the study revealed that there was a relationship between physical activity and dysmenorrhea $(P=0.000)$ and significance value sig $<0.005$. The value of the correlation coefficient was $r=-0.650$ means there was a strong relationship between variables. Conclusion, there is a significant relationship between physical activity and dysmenorrhea in the city of Bandung. Health workers through the UKS program are expected to increase female physical activity through additional sports as a program to prevent dysmenorrhea.
\end{abstract}

Keywords: Adolescence, dysmenorrhea, Physical activity.

\section{INTRODUCTION}

World Health Organization (2014) defines adolescence or puberty as a stage of human life in the form of a transition from childhood to adulthood with an age range of 10-19 years. Regulation of the Minister of Health of the Republic of Indonesia Number 25 of 2014 explains that adolescents are residents with an age range of 10-18 years, at that time there was rapid growth including reproductive functions which affected physical, mental and social roles. Adolescence is associated with the transition from children to adults. This period is the preparation period into adulthood through several stages of development. In addition to physical and sexual maturity, adolescents also experience stages towards social and economic independence, identity building, acquisition of skills for adult life, and the ability to negotiate.

Adolescent reproductive health is a comprehensive health condition, covering physical, mental and social aspects, not just free from reproductive diseases that will disrupt reproductive processes and functions. Changes that occur between men and women are different. During puberty changes in hormonal levels affect secondary sex such as androgen hormones in men and 
estrogen in women. Characteristics of women include growth in pubic hair, armpit hair growth, and menarche (Yuniarti, 2008).

Women of reproductive age have menstruation every month. Menstruation is periodic and cyclic bleeding from the uterus accompanied by endometrial release. It occurs when the inner lining of the uterus decays and discharge (Proverawati \& Misaroh, 2009). Several problems occur during menstruation. Types of menstrual disorders include uterine bleeding dysfunction, dysmenorrhea (pain during menstruation), premenstrual syndrome, and amenorrhea (no menstruation). Menstrual disorders are divided based on the level of comfort (pain or not), the amount of blood coming out, and the problem of menstruation cycle (Pratiwi, 2016).

Women experience different menstrual disorders, one of which is dysmenorrhea. Dysmenorrhea is pain during menstruation which is primary or secondary pain due to an increase of hormone prostaglandin which results in the uterus contracting. Primary dysmenorrhea is pain during menstruation without gynecological disease, while secondary dysmenorrhea is pain during menstruation caused by gynecological diseases (Bobak, 2010). Dysmenorrhea is also defined as a symptom of recurrence, or the medical term is called catamenial pelvic pain, which is painful during menstruation which has a bad effect, such as a disruption of daily activity. Women feel severe pain during menstruation, which is cramps caused by contraction of the smooth muscles of the uterus, anxiety, headache, pain in the middle of the stomach, and fatigue. Dysmenorrhea was a reason for women to go to the doctor for treatment and consultation.

Teenagers who experience dysmenorrhea often experience severe pain and feel like a stabbing in the suprapubic and lumbosacral regions. The pain happened approximately 12 hours on the first day of menstruation, teenagers who experience dysmenorrhea would feel the sensation of heartburn, nausea, vomiting, headache, tend to be irritable, sensitive, and faint. This condition can last for two days or more, according to the length of menstruation each month. The menstrual pain could occur in women of all ages, yet as women getting older and became a mother, the pain is decreased (Bobak, 2010).

WHO data (2012) showed that the incidence of menstrual pain in the world was enormous. On average more than $50 \%$ of girls in every country experience of dysmenorrhea. In the United States, the incidence was $1,769,425$ people or (90\%) adolescents and $10-15 \%$ had severe dysmenorrhoea. In Malaysia, the prevalence of dysmenorrhoea in adolescents was 62.3\% (Ningsih, 2011). Whereas in Indonesia, the incidence of dysmenorrhea was $54.89 \%$ of primary 
Kusila Devia Rahayu: The Relationships Between Physical Activities

dysmenorrhoea and $9.36 \%$ of secondary dysmenorrhoea (Purnamasari, 2013). Thomas and Magos (2009) mentioned that the prevalence of Indonesian adolescent girls who experience dysmenorrhea approximately $43 \%-93 \%$. Based on the results of the study, the incidence of dysmenorrhoea in West Java is quite high, the results of the study found 54.9\% of adolescent girls had dysmenorrhoea, consisting of 24.5\% having mild dysmenorrhoea, $21.28 \%$ having moderate dysmenorrhea and $9.36 \%$ experiencing severe dysmenorrhoea (Arnis, 2012). Although in general dysmenorrhea is not dangerous, it is irritating for women. The level of pain is not the same for every woman. Some are still able to work (occasionally grimacing), and there are other women who threatening of severe pain and unable to do their daily activities (Proverawati and Misaroh, 2009).

Risk factors of dysmenorrhea are first menstruation or menarche at an early age or less than 12 years, women who have never given birth, heavy menstrual blood, long periods of menstruation, smoking, a history of family dysmenorrhea, obesity, and lack of physical activity (Pratiwi, 2016). Physical activity is physical movement carried out by the muscles of the body and its supporting system. Physical activity is any bodily movement produced by skeletal muscles that require energy expenditure. Physical activity is reducing an independent risk factor for chronic diseases, and overall is estimated to cause death globally. Physical activity is classified into 3 namely mild physical activity, moderate physical activity, and heavy physical activity. Teenagers need physical activity because it helps in the process of growth and in a long period of time during life. One of the advantages is a good circulation of blood. Physical activity is also one of the relaxation techniques that can be used to reduce pain when doing physical activity, the body produces endorphins. Endorphine hormones function is the natural sedatives that causing a sense of comfort (Anurogo, 2011).

The incidence of dysmenorrhea increases when women have a lack of physical activity during menstruation, this is because of reducing blood circulation and oxygen. The impact on the uterus is reducing blood flow and oxygen circulation and cause pain. Sports is one of the relaxation techniques that can be used to reduce pain. This is in line with the research conducted by Purnawati et al., 2015 examined the relationship of the level of physical activity with primary dysmenorrhea in adolescents aged 13-15, the study found $77.3 \%$ of respondents had low physical activity, and the majority was experienced dysmenorrhea (67.1\%). Saadah (2014) argued that women who are physically active, the incidence of dysmenorrhea decreases. Women who 
exercise at least once a week can reduce the intensity of pain and discomfort in the lower abdominal area (Proverawati and Misaroh, 2009).

Based on the results of a preliminary study at the Vocational School in Bandung, the head of the youth red cross said that during formal activities such as Monday's ceremonies, every month there were students who asked for resting permission because of dysmenorrhea. Interviews with 10 female students said that six out of ten people experience dysmenorrhea, six out of ten people exercise three times a week with four-dimensional dysmenorrhea pain, while two out of ten students rarely do activities just sitting in class and school canteen, they had dysmenorrhea in scale two. This result was not the same as Bandung Kartika XIX High School, which when interviewed, the female students had moderate activity so that dysmenorrhea was felt in a moderate range.

\section{METHODS}

The type this research was a descriptive correlation method that examined the relationships between variables. the technique of sampling in this research was the total sampling. This research was conducted in the month of February - July 2018 in some high school in Bandung, with a population of 68 respondents people who meet criteria for inclusion. This research used the Baecke Physical Activity Scale and Numeric Rating Scale (NRS) as the questionnaire. Before the data collection, the researcher provided an explanation about how to filling. Data were analyzed using computer programs including editing, coding, data entry, and cleaning. The univariate analysis tested the number of respondents and the intensity of the dysmenorrhea which is presented in the form of a table. The correlation coefficients analysis test used the Spearman rank test.

\section{RESULTS}

Description the level of physical activity in adolescents in the city of Bandung. This study showed that half of the respondents 33 respondents (48.5\%) had a moderate activity level. 
Kusila Devia Rahayu: The Relationships Between Physical Activities

Table 1 Distribution of the frequency of physical activity In Adolescents in the city of Bandung

\begin{tabular}{lll}
\hline Category of activity & Frekuensi (f) & Percent \% \\
\hline Mild & 22 & 32,4 \\
Moderate & 33 & 48,5 \\
Severe & 13 & 19,1 \\
\hline $\mathrm{n}$ & 68 & 100 \\
\hline
\end{tabular}

Table 2. Frequency distribution of the degree of dysmenorrhea in adolescents in the city of Bandung

\begin{tabular}{lll}
\hline Category of the degree of dysmenorrhea & Frekuensi (f) & Percent (\%) \\
\hline Mild pain (1-3) & 13 & 19,1 \\
Moderate pain (4-6) & 36 & 52,9 \\
Severe pain (7-10) & 19 & 27,9 \\
\hline $\mathrm{n}$ & 68 & 100 \\
\hline
\end{tabular}

Table 3 distribution of the frequency Relationship of physical activity with Dysmenorrhea In Adolescents in the city of Bandung

\begin{tabular}{|c|c|c|c|c|c|c|c|c|c|c|}
\hline \multirow{3}{*}{$\begin{array}{l}\text { Physical } \\
\text { Activity }\end{array}$} & \multicolumn{10}{|c|}{ Dismenore } \\
\hline & \multicolumn{2}{|c|}{ Light } & \multicolumn{2}{|c|}{ moderate } & \multicolumn{2}{|c|}{ weight } & \multicolumn{2}{|c|}{ Total } & \multirow{2}{*}{$R$ count } & \multirow{2}{*}{$p$-value } \\
\hline & $\mathbf{F}$ & $\%$ & $\mathbf{F}$ & $\%$ & $\mathbf{F}$ & $\%$ & $\mathbf{F}$ & $\%$ & & \\
\hline Light & 2 & 2,9 & 4 & 5,9 & 16 & 23,5 & 22 & 32,4 & \multirow{5}{*}{$-0,77$} & \multirow{5}{*}{0,000} \\
\hline Moderate & 1 & 1,5 & 31 & 45,6 & 1 & 1,5 & 33 & 48,5 & & \\
\hline \multirow[t]{2}{*}{ weight } & 10 & 14,7 & 1 & 1,5 & 2 & 2,9 & 13 & 19,1 & & \\
\hline & & & & & & & & & & \\
\hline $\mathrm{N}$ & 13 & 19,1 & 36 & 52,9 & 19 & 27,9 & 68 & 100 & & \\
\hline
\end{tabular}

\section{DISCUSSION}

The relationship of physical activity and dysmenorrhea in adolescents in the city of Bandung

The research found that young women had low physical activity $(n=22)$, and 13 adolescent had a mild level of dysmenorrhea. Young women with moderate activities were 33 respondents, and 36 adolescents had moderate dysmenorrhea. 13 adolescents had a high level of physical activities, and the severe dysmenorrhea threated 19 adolescents. The study found the results of the statistical tests P-value $=0000$ ( $\mathrm{sig}<0.005)$, means the Ho rejected, and there was a significant relationship between physical activity and dysmenorrhea in adolescents in Bandung. From the results of the correlation coefficient $r=0.650$-note this showed relationships between 
variables was strong relationships because it is on the range of $0.60-0,799$. Relationships between variables were negative, this means that the more strenuous physical activity the more mild degree of perceived dysmenorrhea.

Physical activity performed by teenagers distinguished by frequency and duration time of activity. Outdoor activities are not so favored because the weather outside is hot or cold so that too much out of sweat and fatigue While physical activity is less independent risk factors for chronic disease, and overall estimated leading cause of death globally (Andrini, 2014). According to the American College of Sports Medicine (ACSM), physical fitness is the ability of someone doing physical activity. Someone who is fit will also be good and substantially to generate the energy required by the body during physical activity and reduce the risk factors for a range of chronic diseases.

Physical activity is any form of body movement that requires the movement of energy and calorie burning, can be either a sport or physical activity every day. Activities on a regular basis can give you an advantage, i.e. improve cardio function and respiratory, reducing the risk of heart disease, as well as reducing anxiety and depression (Anies, 2009). Daily activities carried out by young women demanded a lot of gestures like sitting, physical activity can be either a regular sports where sport can reduce menstrual pain because the muscles of the pelvic floor muscles and hip stretch be relaxed this is because physical activity triggers the body to produce endorphins, naturally occurring opiates which increase the feeling of well-being in addition to reduce pain (Gilly, 2009).

Dysmenorrhea is menstrual pain that occurs in the absence of abnormality on genital appliances or reproduction. The pain occurs when the menstruation happens. The pain is seizures on the rise-and skipping games, usually confined to the lower abdomen, but it can spread to the waist and thighs. On some women found nausea, vomiting, headache, diarrhea, irritability, etc. Dysmenorrhea is suspected as a result of the formation of prostaglandins, which also led to excessive uterine contractions and also resulted in vasospasm arteriolar. With increasing age of women, the pain tends to decline and eventually disappear completely after birth. Each individual has a different response to pain. It is influenced by the individual descriptions of pain, the perception and experience of pain, in teenagers generally they are experiencing pain (Febriana, 2015). 
In addition, there are factors which affect the degree of dysmenorrhea among others, nutritional status, the age of menarche, and psychological. Research conducted by Fitriana and Rahmayani (2013) that aimed to identify factors affecting the incidence of dysmenorrhea in midwifery student, the results revealed there were relationships between nutritional status and incidence of primary dysmenorrhea p-value value $(0.042) \alpha$-value $<(0.05)$. There was a relationship between the age of menarche with primary dysmenorrhea incident in the same respondents with the p-value (0.047)- $\alpha<$ value $(0.05)$. There was a relationship between Psychological and primary dysmenorrhea in midwifery student p-value $(0.010) \alpha$-value $<(0.05)$.

The cases of dysmenorrhea would increase in women who lack physical activity during menstruation. A lack of exercise can lead to decreased blood and oxygen circulation. Its effects on uterine blood flow and circulation are oxygen decreases and cause pain. This is because someone who does an exercise produced endorphin. Endorphin hormone produced in the brain and spinal cord nerves arrangement serves as a natural sedative, manufactured the brain so that it can give rise to a sense of comfort

In this study, the relationship between physical activity and dysmenorrhea was a negative relationship. It means the more often do physical activity the more endorphins produced. It gives a sense of comfort as well as produce analgesic non-specific short term to alleviate the pain. Physical activity has a particular role in lowering dysmenorrhea by lowering anxieties and mental stress. Regular physical activity would stabilize the release hormone endorphin which has a function as the body's natural painkillers so it could blockade a pain in menstruation. Physical activity would also reduce pain through blood vessels in the vasodilatory mechanisms of reproductive organs so that no occurrence of ischemia and prevent the occurrence of dysmenorrhea (Siswantoyo and Aman, 2014).

\section{CONCLUSION}

Half of the adolescents in the city of Bandung have a moderate level of physical activities. The majority of adolescents also have a moderate level of dysmenorrhea. There is a significant relationship between physical activity and dysmenorrhea. Health workers through the UKS program are expected to increase female physical activity through additional sports as a program to prevent dysmenorrhea 
Kusila Devia Rahayu: The Relationships Between Physical Activities

\section{REFERENCES}

Alimul H, A. Aziz. 2009. Kebutuhan Dasar Manusia Aplikasi Konsep dan Proses Perawatan. Jakarta : Salemba Medika.

Al-Mighwar, M (2009). Psikologi Remaja Petunjuk Bagi Guru Dan Orang Tua Bandung : Pustaka Setia

Anies Mkes pkk, 2009. waspada ancaman penyakit tidak menular. pt elex media komputindo. Jakarta.

Anurogo,D. \& Wulandari, A. 2011. Cara Jitu Mengatasi Nyeri Haid.Yogyakarta

Arikunto, S. 2013. Prosedur Penelitian: Suatu Pendekatan Praktik. Jakarta: Rineka Cipta.

Arikunto, Suharsimi, 2002. Prosedur Penelitian Suatu Pendekatan Praktek. Jakarta. PT. Rineka Cipta.

Baecke, J. A., Burema, J., \& Frijters, J. E. 1982. A short questionnaire for the measurement of habitual physical activity in epidemiological studies. The American journal of clinical nutrition, 36(5), 936-942. Diakses pada tanggal 12 Febuari pukul 22.00 Wib

Bobak, L. J. 2010. Buku Ajar Keperawatan Maternitas Edisi 4. Jakarta: EGC.

Bobak, Lowdermilk, Jense. 2012. Buku Ajar Keperawatan Maternitas. Jakarta : EGC

Departemen Kesehatan RI. 2010. Profil Kesehatan Indonesia Tahun 2010. Jakarta : Departemen Kesehatan.

Fitriana, N. W., Utami, F. S., \& Djufri, S. 2017. Hubungan Tingkat Stres Dengan Kejadian Dismenore Pada Mahasiswa D Iv Kebidanan Semester Viii Universitas 'Aisyiyah Yogyakarta (Doctoral dissertation, Universitas' Aisyiyah Yogyakarta). Diakses pada tanggal 29 Juni 2018 pukul 14.00 Wib

Gilly Andrews, 2009, buku ajar kesehatan reproduksi wanita (womens sexual health), EGC, Jakarta.

Handayani, E. Y., \& Rahayu, L. S. 2014. Faktor-Faktor Yang Berhubungan Dengan Nyeri Menstruasi (Dismenorea) Pada Remaja Putri Di Beberapa SMA Di Kabupaten Rokan Hulu. Jurnal Martenity and Neonatal, diakses pada tanggal 02 Juli 2018 pada pukul 20.09 WIB

Irianto, Koes, 2015. Kesehatan Reproduksi. Bandung : Alfabet

Judha M dkk, 2012. Teori pengukuran nyeri persalinan. Yogyakrta : Nuha Medik

Khamzah Siti Nur, 2015. Tanya Jawab Seputar Menstruasi. Yogyakarta : Flash Books

Kozier, Erb, Berman, Snyder. 2009. Buku Ajar Fundamental keperawatan Konsep, proses \& Praktek. Edisi 5. Alih bahasa : Eny,M., Esti, W., Devi, Y. Jakarta: EGC. 
Kusila Devia Rahayu: The Relationships Between Physical Activities

Matanari, Y. Hubungan Pola Makan Dan Aktivitas Fisik Dengan Dismenore Pada Siswi Kelas X MAN 2 Model Medan Tahun 2011. Diakses pada tanggal 27 Juni 2018 Pukul 10.00 WIB

Ningsih, R., Setyowati, S., \& Rahmah, H. 2011. Efektivitas Paket Pereda Nyeri Pada Remaja Dengan Dismenore. Jurnal Keperawatan Indonesia, 16(2), 67-76. Diakses pada tanggal 17 Maret 2018 pukul 11.00 WIB

Nurmalina, Rina. 2011. Pencegahan \& Manajemen Obesitas. Bandung :Elex Media Komputindo.

Notoatmodjo, S. 2010. Metodologi Penelitian Kesehatan. Jakarta: Rineka Cipta.

Nursalam, 2013. Konsep Penerapan Metode Penelitian Ilmu Keperawatan. Jakarta: Salemba Medika.

Paramastri, R., Siti Helmyati, D. C. N., \& Susilo, J. 2016. Hubungan Konsumsi Makanan Cepat Saji dan Aktivitas Fisik dengan Kejadian Dismenore Primer pada Remaja Putri (Doctoral dissertation, Universitas Gadjah Mada). Diakses pada tanggal 27 Juni 2018 Pukul 10.00 WIB

Potter, Patricia A. \& Perry, Anne Griffin. 2005. Buku Ajar Fundamental Keperawatan: konsep, proses, dan praktik. Jakarta: EGC.

Potter \& Perry. 2009. Fundamental Keperawatan. Edisi 7. Jakarta : Salemba Medika Pratiwi 2016.

Proverawati \& Misaroh, 2009, Menarche mentruasi Pertama Penuh Makna. Yogyakarta : Nuha Medika.

Purwoastuti E \& Walyani, 2015. Panduan Materi Kesehatan Reproduksi \& Keluarga Berencana. Yogyakarta : Pustaka Baru Press.

Sarwono. S.W. 2011. Psikologi Remaja. Jakarta: PT Raja Grafindo Persada

Sianipar, O. 2009. Prevalensi Gangguan Menstruasi dan Faktor-Faktor Yang Berhubugan pada Siswi SMU Di Kecamatan Pilo Gadung Jakarta Timur. Maj Kedokteran Indonesia. 59:7. Diakses pada tanggal 17 Maret 2018 pukul 11.00 Wib

Sugiyono, 2016, Metode Penelitian Kombinasi. Bandung : Alfabeta.

U.S. Department of Health and Human Services, Public Health Service, Centers for Disease Control and Prevention, National Center for Chronic Disease Prevention and Health Promotion, Division of Nutrition and Physical Activity. Promoting physical activity: a guide for community action. Human Kinetics. 1999. Diakses pada tanggal 12 Febuari pukul $22.00 \mathrm{Wib}$

Wati, L. R. 2017. Pengaruh Aktifitas Fisik dengan Derajat Dysmenorrhea Primer pada Remaja. Journal of Issues in Midwifery, 1(2), 1-8. Diakses pada tanggal 12 Febuari pukul 22.00 Wib 
Kusila Devia Rahayu: The Relationships Between Physical Activities

Widyastuti, Yani dkk.2009.Kesehatan Reproduksi.Yogyakarta:Fitramaya.

Windastiwi, W., Pujiastuti, W., \& Mundarti, M. 2017. Pengaruh Abdominal Stretching Exercise Terhadap Intensitas Nyeri Dismenorea. Jurnal Kebidanan, diakses pada tanggal 02 Juli 2018 pukul 21.59 WIB.

Wong, D.L et al. 2009. Buku ajar keperawatan pediatrik (Agus Sutarma et al, Penerjemah). Jakarta: Penerbit buku kedokteran EGC. 